\title{
Investigation and Research on the Implementation of "Ideological and Political Courses into Classroom" in Higher Vocational Physical Education Class
}

\author{
Kong Huangsheng \\ Shanghai Vocational and Technical College of Agriculture and Forestry \\ Shanghai, China 201600 \\ E-mail: konghs@shafc.edu.cn
}

\begin{abstract}
Sports teaching in higher vocational colleges should not only undertake the task of imparting sports knowledge and skills, but also have the responsibility of cultivating college students 'moral emotion, character of will, and social adaptive behavior. Under the guidance of the concept of full education, in order to better play the positive role of physical education in the training of talents, it is particularly important to implement the implementation of politics into the classroom in physical education. By means of literature, questionnaire survey, interview and statistical analysis, we systematically analyze and discuss the implementation of politics and politics in physical education. Strive to research and explore the teaching concept, teaching goal, teaching content, teaching implementation, teaching evaluation system in the teaching of physical education in order to improve the effectiveness of moral education infiltration in physical education, and it is of great significance to deepen the reform of physical education teaching in the new era.
\end{abstract}

Keywords-Physical education; Ideological and Political Courses into Classroom; Moral education infiltration; Sports options class

\section{INTRODUCTION}

Ideological and political education in colleges and universities(hereinafter referred to as thought politics) aims to cultivate socialist core values, undertakes the education of college students to carry out Marxist standpoints and methods, helps students to establish correct outlook on life and values, and develops good behavior habits. Teaching task. In the course of physical education, some moral emotion and character of will of college students are more likely to appear naturally, and they are also more likely to be influenced and infected. At present, as the main channel of ideological and political education for college students, the ideological and political courses in colleges and universities are not attractive enough for ordinary higher vocational college students because they are theoretically preaching. They are no longer widely welcomed by college students. Therefore, the research put forward the suggestion that the school should infiltrate all education into moral education. For example, the United States, Singapore, Japan, etc., all courses, including school sports, are used as carriers and channels for moral education, laying the foundation for students 'moral development in an all-round way. "Moral education is the soul, destination and value of all education in the school." In order to improve the reality, effectiveness and diversity of moral education for college students, we should draw on the experience of foreign moral education and, while keeping the main channel of teaching courses in China's unique ideological and political courses unchanged, further promote the reform of Kechengsizheng's teaching in ordinary colleges and universities. So that the explicit education of the thought course and the invisible education of the sports course achieve a high degree of integration in the movement of the sports course and the static of the thought course, forming a joint force and innovative development.

\section{RESEARCH OBJECTS AND METHODS}

\section{A. Subjects studied}

Taking 132 freshmen from a higher vocational college in Shanghai as the research object.

\section{B. Methods of study}

Questionnaire survey method: 140 questionnaires were issued, 132 effective questionnaires were recovered, and the recovery rate was $94.3 \%$

Logical analysis: According to the survey, statistical results and the relationship between each project, conduct theoretical and logical research and analysis.

Mathematical statistics method: All survey data are managed and analyzed through the software SPSS11.5. The ttest and single-factor variance analysis method are used to analyze the current situation of political thinking in new sports courses in higher vocational colleges and analyze the significance of their differences. 


\section{EXPERIMENTAL RESULTS AND ANALYSIS}

\section{A. Current Situation of Physical Education before the} Implementation of Political Thought in the Classroom

Teaching concept, teaching goal, teaching content, teaching implementation and teaching evaluation are the complete links of higher vocational sports teaching. As shown in table 1, the total level of thought politics in higher vocational education is 9780.00 , of which the minimum value is 32.00 , the maximum value is 112.00 , the average level is 73.83, and the variance is 14.8767; The level of teaching philosophy is 1962.00 , of which the minimum value is 7.00 , the maximum value is 21.00 , the average level is 14.87 , and the variance is 3.0731; The teaching target level is 1906.00 , of which the minimum value is 6.00 , the maximum value is
20.00 , the average level is 14.48 , and the variance is 2.67 ; The level of teaching content is 1987.00 , of which the minimum value is 8.00 , the maximum value is 24.00 , the average level is 15.210 , and the variance is 2.81 ; The level of teaching implementation is 1931.00, of which the minimum value is 6 . 00 , maximum 25.00, average level 14.01, variance 3.51; The level of teaching evaluation is 1994.00 , of which the minimum value is 5.00 , the maximum value is 22.00 , the average level is 15.26 , and the variance is 2.90 .

It can be seen that the overall level of ideological education in higher vocational education is not high, the lack of innovation in teaching steps, the problem that moral education still has old ideas and the dependence of educational paths, and the infiltration of physical education moral education has not received enough attention.

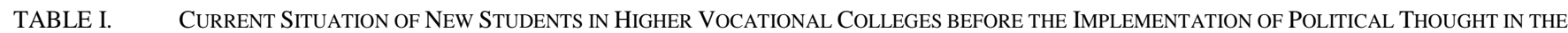
CLASSROOM

\begin{tabular}{ccccccc}
\hline Item & $\mathrm{N}$ & Minimum & Maximum & Sum & Mean & Std. Deviation \\
Statistic & Statistic & Statistic & Statistic & Statistic & Statistic \\
\hline Teaching philosophy & 132 & 7.00 & 21.00 & 1962.00 & 14.87 & 3.0731 \\
Teaching objectives & 132 & 6.00 & 20.00 & 1906.00 & 14.48 & 2.6719 \\
Teaching content & 132 & 8.00 & 24.00 & 1987.00 & 15.21 & 2.8142 \\
Teaching implementation & 132 & 6.00 & 25.00 & 1931.00 & 14.01 & 3.5163 \\
Teaching evaluation & 132 & 5.00 & 22.00 & 1994.00 & 15.26 & 2.9012 \\
Total level & 132 & 32.00 & 112.00 & 9780.00 & 73.83 & 14.9767 \\
\hline
\end{tabular}

The ideological aspect, psychological aspect, consciousness aspect, and behavior aspect are the complete links of moral education infiltration. Table 2 The survey of the influence of moral education infiltration before the new students in higher vocational colleges implemented thinking into the classroom shows that the total level of sports teaching thinking into the classroom is 4740.00 , in which, Minimum value 3.00, maximum value 51.00; Among them, the ideological aspect of sports teaching thinking into the classroom is 2021.00, the minimum value is 3.00 , and the maximum value is 21.00; The psychological aspect of sports teaching thinking into the classroom is 1861.00 , of which the minimum value is 5.00 and the maximum value is 21.00 ; The consciousness aspect of sports teaching thinking into the classroom is 1887.00 , of which the minimum value is 2.00 and the maximum value is 25.00; Sports teaching thought about the behavior of the classroom 1971.00, of which, the minimum value of 4 . 00, maximum 26.00 .

It can be seen that there is no consensus among teachers and students on the importance and necessity of moral education, and there is not enough emphasis on moral education in the practice of school education. The higher vocational education pays relatively little attention to moral education infiltration in various disciplines. Among them, the moral education infiltration in physical education has not been paid enough attention to in the concrete implementation.

TABLE II. THE INFLUENCE OF MORAL EDUCATION INFILTRATION ON THE NEW STUDENTS IN HIGHER VOCATIONAL COLLEGES BEFORE THE IMPLEMENTATION OF THE THOUGHT OF POLITICS INTO THE CLASSROOM

\begin{tabular}{|c|c|c|c|c|c|c|}
\hline Item & $\begin{array}{c}\mathrm{N} \\
\text { Statistic }\end{array}$ & $\begin{array}{l}\text { Minimum } \\
\text { Statistic }\end{array}$ & $\begin{array}{l}\text { Maximum } \\
\text { Statistic }\end{array}$ & $\begin{array}{c}\text { SuM } \\
\text { Statistic }\end{array}$ & $\begin{array}{c}\text { Mean } \\
\text { Statistic }\end{array}$ & $\begin{array}{c}\text { Sed.Deviation } \\
\text { Statistic }\end{array}$ \\
\hline Thought Dimensions & 132 & 3.00 & 21.00 & 2021.00 & 15.37 & 2.9356 \\
\hline Psychological dimension & 132 & 5.00 & 21.00 & 1861.00 & 14.19 & 6.6918 \\
\hline Consciousness dimension & 132 & 2.00 & 25.00 & 1887.00 & 14.21 & 3.5142 \\
\hline Behavior dimension & 132 & 4.00 & 26.00 & 1971.00 & 14.91 & 4.3165 \\
\hline overall & 132 & 3.00 & 51.00 & 4740.00 & 38.67 & 7.4567 \\
\hline
\end{tabular}

\section{B. Current Situation of Physical Education after the} Implementation of Political Thought in the Classroom

Teaching ideas, teaching goals, teaching content, teaching implementation, teaching evaluation is the complete link of sports teaching. To explore the important variables of moral education of students with different gender in physical education classroom, as shown in Table 3, the cognition and influence of students with different gender on the teaching of physical education in the classroom are significantly different.
The total level of thought politics into the classroom, $\mathrm{F}=6.12$, $\mathrm{P}=0.016<0.05$, There are significant differences between male and female students, and after-action analysis shows that, $71.22<77.62$ 。 Specifically, in the dimension of teaching philosophy, $\mathrm{F}=10.01, \mathrm{P}=0.001<0.01$, Therefore, there is a significant difference between male and female students. In the teaching target dimension, $\mathrm{F}=2.24, \mathrm{P}=0.135>0.05$, Therefore, there is no significant difference between male and female students. In the content dimension, $\mathrm{F}=2.36$, 
$\mathrm{P}=1.26>0.005$, There is no significant difference between male and female students. In the implementation dimension of teaching, $\mathrm{F}=6.32, \mathrm{P}=0.17>0.005$, Therefore, there is no significant difference between male and female students. In the teaching evaluation dimension, $\mathrm{F}=6.89, \mathrm{P}=.008<0.01$, Therefore, the difference between male and female students is significant.
It can be seen that the overall understanding level of students after the implementation of politics into the classroom in sports teaching has improved, and there is no significant difference between the teaching goals and teaching content in teaching steps; Teaching concept, teaching implementation, teaching evaluation dimension female students are more positive than male students, and there are significant differences.

TABLE III. SITUATION OF NEW STUDENTS IN HIGHER VOCATIONAL COLLEGES AFTER THE IMPLEMENTATION OF THE POLITICAL POLICY INTO THE CLASSROOM

\begin{tabular}{|c|c|c|c|c|c|c|}
\hline Item & $\begin{array}{l}\text { Analysis } \\
\text { variables }\end{array}$ & $\begin{array}{c}\mathrm{N} \\
\text { Statistic }\end{array}$ & $\begin{array}{c}\text { Mean } \\
\text { Statistic }\end{array}$ & $\begin{array}{c}\text { Std. } \\
\text { Deviation }\end{array}$ & $\mathrm{F}$ & Sig \\
\hline Teaching & male & 63 & 14.67 & 3.1476 & 10.01 & .001 \\
\hline philosophy & female & 69 & 15.51 & 2.1678 & & \\
\hline Teaching & male & 63 & 13.68 & 2.7018 & 2.24 & .132 \\
\hline objectives & female & 69 & 16.12 & 2.1314 & & \\
\hline Teaching & male & 63 & 14.76 & 2.8913 & 2.36 & .126 \\
\hline content & female & 69 & 15.89 & 2.4017 & & \\
\hline Teaching & male & 63 & 13.10 & 3.6801 & 6.32 & .017 \\
\hline implementation & female & 69 & 14.67 & 2.6517 & & \\
\hline Teaching & male & 63 & 15.01 & 3.0124 & 6.89 & .008 \\
\hline evaluation & female & 69 & 15.43 & 2.2136 & & \\
\hline Total level & Male & 63 & 71.22 & 15.4332 & 6.22 & .016 \\
\hline & female & 69 & 77.62 & 11.5662 & & \\
\hline
\end{tabular}

Similarly, from the perspective of gender, the differences in the acceptance of moral education between male and female students after the implementation of politics into the classroom are considered. As shown in table 4, the differences in the acceptance of moral education between male and female students in physical education are significantly different among students of different genders. Overall level of moral education in physical education, $\mathrm{F}=6.17, \mathrm{P}=0.016<0.05$, There are significant differences between male and female students. Specifically, in the thought dimension, $\mathrm{F}=1.01$, $\mathrm{P}=0.671>0.01$, Therefore, there is no significant difference between male and female students. In the consciousness dimension, $\mathrm{F}=13.36, \mathrm{P}=0.003<0.01$, Therefore, the difference

between male and female students is significant. In the behavior dimension, $\mathrm{F}=2.32, \mathrm{P}=0.174>0.005$, Therefore, there is no significant difference between male and female PE teachers.

It can be seen that the teachers and students of colleges and universities can reach a consensus on the importance and necessity of moral education. However, the degree of moral education in the practice of school education is slightly insufficient. Among them, the moral education in sports teaching penetrates in the concrete implementation. The psychological dimension and the consciousness dimension of girls are obviously better than boys, and there are significant differences.

TABLE IV. DIFFERENCE IN ACCEPTANCE OF MORAL EDUCATION BETWEEN MALE AND FEMALE STUDENTS IN HIGHER VOCATIONAL COLLEGES AFTER THE IMPLEMENTATION OF THOUGHT POLITICS INTO THE CLASSROOM

\begin{tabular}{ccccccc}
\hline Item & Analysis variables & $\mathrm{N}$ & Mean & Std. & F & Sig \\
& & Statistic & Statistic & Statistic & & \\
\hline Thought & male & 63 & 14.67 & 1.9432 & 1.01 & .671 \\
Dimensions & female & 69 & 15.51 & 1.7681 & & \\
Psychological & male & 63 & 13.68 & 1.9713 & 4.24 & .036 \\
dimension & female & 69 & 16.12 & 1.6719 & & \\
Consciousness & male & 63 & 14.76 & 1.8918 & 13.36 & .003 \\
dimension & female & 69 & 15.89 & 1.6714 & & \\
Behavior & male & 63 & 13.10 & 3.6806 & 2.32 & .174 \\
dimension & female & 69 & 14.67 & 2.6845 & & \\
Total level & male & 63 & 67.01 & 9.3124 & 6.17 & .016 \\
& female & 69 & 72.43 & 7.2136 & & \\
\hline
\end{tabular}

\section{CONCLUSIONS AND RECOMMENDATIONS}

\section{A. Conclusion}

1) There is still the problem of outdated ideas in university curriculum thinking and politics, and the integration of disciplines has not received enough attention.
Through the investigation, although it can be seen that this moral education path into the subject teaching system has been highly valued by a considerable number of schools, but also by many college students. However, it is still revealed that there are still problems such as outdated ideas, dependence on educational paths, and lack of attention to the integration of disciplines in school moral education. The survey showed that the total level of politics in higher vocational education was 
9780.00 , of which the minimum value was 32.00 , the maximum value was 112.00 , the average level was 73.83 , and the variance was 14.8767 .

2) There is a gap between the effect of moral education infiltration and the expectation in college physical education teaching.

The above investigation shows that students have carried out different levels of moral education infiltration practice in sports teaching, but the infiltration situation is not satisfactory. The total level of sports teaching before the experiment was 4740.00, of which the minimum value was 3.00 and the maximum value was 51.00; After the experiment, the overall level of physical education received moral education has improved. $\mathrm{F}=6.17$, the difference between male and female students is significant.

3) The content of the evaluation of physical education in higher education is not comprehensive enough.

The Outline of Teaching Instruction for Physical Education Courses in National Institutions of Higher Education puts forward clear criteria for the learning evaluation of college students and points out: "The learning evaluation of students should be an evaluation of the learning effect and process. The facts that mainly include physical fitness and sports skills, cognition, learning attitudes and behaviors, communication and cooperation spirit, and emotional expression, etc., prove that the evaluation of the learning of sports courses in the new period required by the new outline is relatively complete. However, in the actual operation process, Some colleges and universities are still influenced by traditional ideas. The evaluation of college students 'sports learning still pays partial attention to sports skills and physical fitness, and ignores the evaluation of moral education. Obviously, the separation in practice still exists, and the research results show that. After the experiment, in the dimension of teaching evaluation, $\mathrm{F}=6.89, \mathrm{P}=0.008$, so the difference between male and female students is significant.

4) The method of curriculum thinking and administration in college sports teaching needs to be innovated.

The interview results show that although most physical education teachers realize the importance of curriculum thinking and politics in physical education teaching, they have the intention and idea of infiltrating through moral education, but they can not be truly implemented due to the limitations of teaching time and other factors, resulting in the separation of theory and practice. According to a senior physical education teacher at a university, physical education teachers often can only and often communicate with students before class and after class for a short period of time in order to complete the explanation of physical education knowledge and the teaching of sports skills in a limited time. In the exchange, answer questions, talk about ideals, talk about spirit, talk about will, and educate college students in ideological guidance and behavior norms. Some teachers, under the guidance of the goal of moral education, actively carried out moral education infiltration in the teaching, but, in the concrete implementation of moral education infiltration, there is a strong arbitrariness, it seems to be no law, and it is difficult to obtain moral education effectiveness. All these situations show that physical education teachers in the teaching lack of moral education in the method of penetration innovation.

\section{B. recommendations}

1) The awareness of physical education teachers about classroom politics is continuously strengthened.

In the course of each course, the course thought politics is carried out. This approach has a high degree of recognition in higher vocational education and can be implemented in the actual education and teaching process. This requires our physical education teachers to implement the concept of full education and comprehensive education, recognize the moral education value of physical education teaching, improve the sense of responsibility and mission of moral education infiltration, and actively strengthen moral education infiltration in physical education teaching. In the course of teaching, "thematic education and guidance activities", "infiltration in teaching" and "extra-curricular practice activities" are often carried out.

2) Pay attention to the improvement of the goal design of curriculum thinking and politics in higher vocational education.

At present, the goal of all-round development of talents training, sports teaching not only needs to teach sports knowledge, skills and the development of students 'ability, but also needs to improve knowledge ability and develop a sound personality. Therefore, in the course of teaching design, physical education teachers should establish the concept of comprehensive education and pay attention to the all-round development of students 'knowledge, skills, personality quality, ability and behavior. Only by reflecting the corresponding goal of moral education in the teaching design can we guide and motivate teachers to pay attention to moral education infiltration in teaching, and provide basis for evaluating the effect of curriculum thinking and administration.

3) Enriching the method of curriculum thinking in higher vocational sports teaching.

Physical education teachers have a deep understanding of the characteristics and content of curriculum thinking, and after clarifying the goal of moral education, they need to constantly explore, innovate, master rich methods of curriculum thinking and apply them to the practice of physical education teaching. Specifically speaking, it is what kind of concrete way to convey the influence of moral education in teaching and realize the goal of curriculum thinking.

4) Scientific Evaluation of the Educational Effect of Curriculum Thought in Higher Vocational Physical Education Teaching

For a complete and effective physical education teaching process, teaching evaluation is an essential and important link. The evaluation of curriculum thinking and administration in physical education can judge the concrete implementation and effect of curriculum thinking and politics, achieve the effect of moral education, and then timely feedback information to students and teachers, and quickly discover and deal with the problems that arise in teaching and learning. To evaluate the infiltration effect of moral education in physical education, we 
should make a comprehensive evaluation from two aspects: teachers and students.

\section{REFERENCES}

[1] Lin Kesong. Research on the professional development path of professional education teachers in workplace learning and professional innovation [D]. Chongqing: Doctoral dissertation of Southwest University, 2014. (23). China.

[2] Study on Moral Infiltration in the Public Sports Teaching of Marley University [D]. Master's degree thesis of Beijing University of Physical Education, 2017. China.

[3] Du Wei. Analysis of Moral Education in Physical Education Teaching in Colleges and Universities [J]. Chinese Adult Education, 2009,(22). China.

[4] Wang Tong. The Moral Value and Realization of Physical Education Teaching in Colleges and Universities in the New Period[J]. Chinese Adult Education, 2012, (17). China.

[5] Swaner Leveraging for physical and social return: a review of the property[J]. Library Administration, 2005. 